\title{
Rootstocks effect on plant nutrition concentration in different organ of grafted watermelon
}

\author{
Halit Yetisir ${ }^{*}$, A. Erhan Özdemir ${ }^{2}$, Veysel Aras ${ }^{3}$, Elif Candır², Ömer Aslan ${ }^{4}$ \\ ${ }^{1}$ Department of Horticulture, Faculty of Agriculture, University of Erciyes, Kayseri, Turkey; \\ *Corresponding Author: yetisir1@yahoo.com \\ ${ }^{2}$ Department of Horticulture, Faculty of Agriculture, University of Mustafa Kemal, Hatay, Turkey \\ ${ }^{3}$ Alata Horticultural Research Institute Erdemli, Mersin, Turkey \\ ${ }^{4}$ Ministry of Agriculture and Rural Affair, Silifke District Directorate Silifke, Mersin, Turkey
}

Received 19 March 2013; revised 19 April 2013; accepted 10 May 2013

Copyright (C) 2013 Halit Yetisir et al. This is an open access article distributed under the Creative Commons Attribution License, which permits unrestricted use, distribution, and reproduction in any medium, provided the original work is properly cited.

\section{ABSTRACT}

In this study carried out in 2009 and 2010 growing seasons, effect of rootstocks on plant nutrition partitioning in grafted watermelon onto four gourd rootstocks was investigated. Ferro, RS841 (Cucurbita maxima x C. moschata) and Argentario and Macis (Lagenaria hybrid) were used as rootstocks. Crimson Tide and Crisby watermelon cultivars were used as scion. Grafted and ungrafted seedlings were produced by a commercial seedling company. Plants were grafted by one cotyledon grafting techniques. Experiment was conducted in Alata Horticultural Research Station in Mersin. The grafted plants were planted under low tunnel in early spring and regular cultural practices for watermelon were applied. Plant nutrition concentrations were determined in leaf, fruit rind, fruit flesh and seeds. Leaf sample was taken at flowering stage, rind, flesh and seed sample were taken from fully mature fruit. Nitrogen concentration was determined by modified Kjheldahl methods. Phosphorous concentration was determined by vanadomolybdophosphoric acid method. $\mathrm{K}, \mathrm{Ca}$, $\mathrm{Mg}, \mathrm{Fe}, \mathrm{Mn}, \mathrm{Zn}$ and $\mathrm{Cu}$ concentration of samples were determined by atomic absorption spectrophotometry. Plant nutrient concentration in leaf, rind, flesh and seed were significantly affected by rootstocks. Increase in concentration of $\mathrm{N}, \mathrm{P}, \mathrm{K}, \mathrm{Ca}$ and $\mathrm{Mg}$ in leaves was not observed in grafted plant. Ungrafted plant had higher concentration of $\mathrm{Fe}, \mathrm{Mn}, \mathrm{Zn}$ and $\mathrm{Cu}$ in their leaves. $\mathrm{Ca}$ concentration in rind of fruits from grafted watermelon was higher than ungrafted control plant except Crimson Tide/Macis and
Crimson Tide/Argentario graft combinations. Plant nutrition content of fruit flesh was significantly affected by rootstocks and scion. Magnesium, $\mathrm{Fe}, \mathrm{Zn}$ and $\mathrm{Mn}$ concentration of seed was not significantly influenced by rootstocks and scion while other plant nutrient content was significantly affected rootstocks and scion.

Keywords: Watermelon; Grafting; Rootstocks; Plant Nutrition Partitioning

\section{INTRODUCTION}

Watermelon (Citrullus lanatus (Thunb.) Matsum and Nakai) is one of the most economically important and widely cultivated vegetable crops in Turkey and in the Mediterranean region. Turkey is the world's second largest watermelon producing country after China, with 3.86 $\times 10^{6}$ t per year [1]. Watermelon has been grown intensively for many years in certain regions of the country. One of the most serious problems of watermelon production is a decrease in yield due to soil-borne diseases, in particular Fusarium, and successive cropping. One of the most effective methods in controlling Fusarium wilt of watermelon is crop rotation, suggesting that watermelon should not be cultivated at least for five years in the same field infested with the Fusarium wilt pathogen [2]. On the other hand, grafting of susceptible varieties onto resistant rootstocks may enable the control of some soilborne diseases and has positive impact on yield and quality [3,4-6]. Purposes of grafting in watermelon were to control soil-borne disease such as Fusarium wilt [7-9], to promote the mineral nutrient uptake [10] and plant growth $[7,11]$, but the objectives of grafting have increased significantly over the years. For instance, graft- 
ing have been used to improve resistance against low [12] and high temperatures [13], against iron chlorosis in calcareous soils [14], to improve salinity tolerance of plant $[14,15]$, to enhance nutrient absorption [16], to improve water use [17], to minimize copper toxicity [18] to improve alkalinity tolerance [19] and to enhance tolerance to excessive water in soil [20].

Effects of rootstock on uptake, translocation and utilization of plant nutrients were reported in previous studies [21-24]. Nevertheless, no published data is available concerning the effects of rootstocks on plant nutrient concentration of different plant organs of watermelon. The objective of this work was to investigate the effects of grafting on plant nutrient concentration of different organs of watermelon.

\section{MATERIALS AND METHODS}

The experiment was conducted in spring seasons of 2009 and 2010 in Alata Horticultural Research Station in Mersin-Turkey. Ferro, RS841 (Cucurbita maxima x C. moschata) and Argentario and Macis (Lagenaria hybrid) were used as rootstocks. Crimson Tide and Crisby watermelon cultivars were used as scion. Grafted and ungrafted seedlings were produced by a commercial seedling company (Grow Fide, Antalya, Turkey). The grafted plants grown in greenhouse were transplanted in low tunnel on March 12, 2009 and March 15, 2000 and the tunnels were removed when the outside air temperature was suitable $\left(20^{\circ} \mathrm{C}-25^{\circ} \mathrm{C}\right)$ for watermelon growth. Soil texture of experimental area was sandy. Plants were fertilized with $180 \mathrm{~kg} \mathrm{~N} \mathrm{ha}^{-1}, 200 \mathrm{~kg} \mathrm{P}_{2} \mathrm{O}_{5} \mathrm{ha}^{-1}$ and $180 \mathrm{~kg}$ $\mathrm{K}_{2} \mathrm{O} \mathrm{ha}^{-1}$. Micro nutrient fertilization was not applied. Total $\mathrm{P}$ was applied before transplanting to the field. Nitrogen and $\mathrm{K}_{2} \mathrm{O}$ were divided into three equal portions. The first portion was applied before transplanting to the field, the second portion was 20 days after transplanting and the third portion was 40 days after transplanting in the field. The experimental design was a completely randomized block design. Each treatment was replicated four times with 20 plants in each replicate. Plants were grown with $3.0 \times 0.6 \mathrm{~m}$ spacing.

Leaves were sample at flowering stage while fruit flesh, rind, and seed were sampled from fully ripe fruits for macro (N, P, K, Ca and $\mathrm{Mg}$ ) and micro (Fe, $\mathrm{Cu}, \mathrm{Mn}$ and $\mathrm{Zn}$ ) plant nutrient analysis. Nitrogen concentration was determined by modified Kjheldahl methods. Phosphorous concentration was determined by vanadomolybdophosphoric acid method. $\mathrm{K}, \mathrm{Ca}, \mathrm{Mg}, \mathrm{Fe}, \mathrm{Mn}, \mathrm{Zn}$ and $\mathrm{Cu}$ concentration of samples were determined by atomic absorption spectrophotometry.

Analysis of variance was performed using SAS [25]. Means were separated using the LSD method at 0.05 significance level.

\section{RESULTS}

\subsection{Leaf}

Leaf mineral composition of grafted watermelons onto different rootstocks was presented in Table 1. Rootstocks effect on leaf mineral composition of grafted watermelon was significant. The highest $\mathrm{N}$ concentration of leaf was recorded in C.T./Ferro while the lowest $\mathrm{N}$ was determined in Cr./Ferro combination. Same results were observed in $\mathrm{P}$ content. The highest $\mathrm{K}$ content was recorded in leaf of C.T./Argentario, lowest $\mathrm{K}$ content was determined in $\mathrm{Cr} / \mathrm{RS} 841$. Cr./Ferro had the highest Ca content while the lowest $\mathrm{Ca}$ content was in C.T./Macis. Crisby had higher $\mathrm{Ca}$ content than Crimson Tide. The highest $\mathrm{Mg}$ was determined in Cr./Ferro while C.T./Macis had the lowest $\mathrm{Mg}$. The highest Fe was recorded in ungrafted Crisby. Crimson Tide and other graft combinations had similar Fe content (80 - 97 ppm). Ungrafted control plants had higher content of $\mathrm{Zn}$ than grafted plants.

Ungrafted Crisby had the higher content of $\mathrm{Zn}$ while the lowest $\mathrm{Zn}$ content determined in C.T./Ferro. Similar results were found for Mn. Crimson Tide and C.T./Macis had the highest $\mathrm{Cu}$ content while the lowest $\mathrm{Cu}$ content was determined in Cr./RS841, Cr./Ferro, Cr./Argentario and C.T./Argentario (Table 1).

\subsection{Fruit Rind}

Fruit rind $\mathrm{N}$ concentration was significantly influenced by both rootstocks and scion. Crisby and its graft combinations had higher content of $\mathrm{N}$ in the rind except Cr./Argentario. The highest $\mathrm{N}$ was determined in Crisby grafted onto Ferro and RS841 whereas the lowest N was determined in ungrafted Crimson Tide.

Grafting onto different rootstocks significantly increased the rind $\mathrm{N}$ content of Crisby while the rind $\mathrm{N}$ content of Crimson Tide was not significantly affected. Similar results were obtained for $\mathrm{P}$ content of fruit rind (Table 2). The highest $\mathrm{K}$ was determined in rind of Cr./Ferro and Crsiby while the lowest $\mathrm{K}$ was recorded in C.T./Argentario. Ungrafted Crisby and its graft combinations had higher $\mathrm{K}$ concentration in fruit rind than Crimson Tide and its graft combinations. Ca content of the rind was affected by rootstocks and cultivars. The highest Ca was recorded in Cr./Ferro and C.T./Ferro while lowest $\mathrm{Ca}$ was in Crimson Tide grafted onto Macis and Argentario. The plants grafted onto Ferro and RS841 higher $\mathrm{Mg}$ concentration in the fruit rind than the controls and the plants grafted onto Lagenaria rootstocks. Crisby grafted onto Macis had the lowest $\mathrm{Mg}$ content in the rind. Iron concentration of fruit rinds was significantly affected by rootstocks and scion. Grafting did not cause significant increase in Fe concentration of fruit rinds. Ungrafted Crimson Tide had the highest $\mathrm{Fe}$ and the lowest Fe was determined in C.T./RS841, Cr./Macis and 
Table 1. Macro (\%) and micro (ppm) plant nutrient concentration of grafted watermelon leaf.

\begin{tabular}{ccccccccccc}
\hline Combinations & $\mathrm{N}$ & $\mathrm{P}$ & $\mathrm{K}$ & $\mathrm{Ca}$ & $\mathrm{Mg}$ & $\mathrm{Fe}$ & $\mathrm{Zn}$ & $\mathrm{Mn}$ & $\mathrm{Cu}$ \\
\hline C.T./Ferro & 3.14 & 0.21 & 1.56 & 2.74 & 0.38 & 80.3 & 22.0 & 23.1 & 11.4 \\
Cr./Ferro & 2.46 & 0.21 & 1.39 & 4.30 & 0.63 & 90.7 & 24.9 & 28.4 & 10.5 \\
C.T./RS841 & 2.57 & 0.25 & 1.58 & 3.61 & 0.56 & 90.7 & 25.3 & 29.4 & 12.3 \\
Cr/RS841 & 2.74 & 0.23 & 1.25 & 3.79 & 0.62 & 84.8 & 24.6 & 26.1 & 10.1 \\
C.T./Macis & 2.81 & 0.23 & 1.50 & 2.37 & 0.21 & 82.8 & 30.8 & 29.6 & 13.1 \\
Cr./Macis & 2.60 & 0.25 & 1.49 & 3.57 & 0.30 & 96.8 & 30.4 & 37.5 & 12.2 \\
C.T./Agentario & 2.63 & 0.21 & 1.70 & 3.53 & 0.36 & 79.8 & 30.0 & 39.3 & 10.7 \\
Cr./Agentario & 2.62 & 0.22 & 1.36 & 3.80 & 0.34 & 86.4 & 33.6 & 38.1 & 10.5 \\
Crimson Tide & 2.71 & 0.26 & 1.67 & 3.44 & 0.38 & 86.9 & 33.0 & 44.7 & 13.1 \\
Crisby & 2.88 & 0.33 & 1.51 & 3.85 & 0.43 & 130.9 & 44.3 & 56.7 & 12.4 \\
Lsd 0.05 & 0.03 & 0.02 & 0.04 & 0.09 & 0.03 & 6.3 & 0.9 & 1.7 & 0.4 \\
\hline
\end{tabular}

Table 2. Macro (\%) and micro (ppm) plant nutrient concentration in rind of grafted watermelon.

\begin{tabular}{cccccccccc}
\hline Graft combinations & $\mathrm{N}$ & $\mathrm{P}$ & $\mathrm{K}$ & $\mathrm{Ca}$ & $\mathrm{Mg}$ & $\mathrm{Fe}$ & $\mathrm{Zn}$ & $\mathrm{Mn}$ & $\mathrm{Cu}$ \\
\hline C.T./Ferro & 2.50 & 0.35 & 3.97 & 0.53 & 0.20 & 33.6 & 12.0 & 2.7 & 3.3 \\
Cr./Ferro & 3.20 & 0.48 & 4.32 & 0.55 & 0.18 & 27.9 & 15.0 & 5.1 & 2.8 \\
C.T./RS841 & 1.86 & 0.35 & 3.60 & 0.32 & 0.16 & 24.2 & 15.0 & 2.9 & 3.0 \\
Cr./RS841 & 3.10 & 0.40 & 3.93 & 0.32 & 0.15 & 29.7 & 14.8 & 3.7 & 2.7 \\
C.T./Macis & 1.85 & 0.30 & 3.29 & 0.18 & 0.10 & 40.3 & 12.6 & 2.7 & 2.0 \\
Cr./Macis & 2.65 & 0.39 & 3.54 & 0.36 & 0.14 & 23.8 & 14.0 & 3.1 & 4.6 \\
C.T./Agentario & 2.03 & 0.33 & 2.93 & 0.16 & 0.13 & 22.2 & 13.9 & 2.2 & 2.3 \\
Cr/Agentario & 2.50 & 0.36 & 3.26 & 0.23 & 0.12 & 31.2 & 12.3 & 2.3 & 2.0 \\
Crimson Tide & 1.80 & 0.36 & 3.65 & 0.21 & 0.12 & 51.4 & 15.9 & 3.0 & 2.6 \\
Crisby & 2.05 & 0.41 & 4.30 & 0.32 & 0.15 & 27.9 & 14.5 & 3.9 & 2.0 \\
Lsd 0.05 & 0.31 & 0.02 & 0.3 & 0.02 & 0.01 & 2.5 & 1.8 & 0.5 & 0.7 \\
\hline
\end{tabular}

C.T./Argentario. Grafting onto different rootstocks did not significantly increase $\mathrm{Zn}$ content of the fruit rinds. C.T./Macis, Cr./Argentario and C.T./Ferro had the lowest $\mathrm{Zn}$ in the rind and other combinations had higher $\mathrm{Zn}$ in the rind. Manganese concentration of fruit rind was significantly affected both rootstocks and scion. The highest Mn concentration was determined in rind of the fruit harvested from $\mathrm{Cr}$./Ferro while the lowest Mn concentration was recorded in the plants grafted onto Argentario. Ungrafted Crisby and Cr./Ferro and Cr./RS841 had higher $\mathrm{Mn}$ concentration in the rind than other graft combinations and Crimson Tide. Cupper content of the rind was varied based on rootstock and scion. The highest $\mathrm{Cu}$ content was determined in Crisby grafted onto
Macis while Cr./Argentario, C.T./Macis and ungrafted Crisby had the lowest $\mathrm{Cu}$ concentration.

\subsection{Fruit Flesh}

Mineral composition of the fruit flesh was significantly affected by rootstocks and scions (Table 3 ). The fruit flesh harvested from Cucurbita rootstocks had higher $\mathrm{N}$ concentration except C.T./RS841 graft combination. Phosphorous content of the fruit flesh showed significant variation based on rootstock and scion. Cr./Macis, C.T./Argentaio, Cr./Macis and ungrafted Crisby had lower P concentration than others. Grafting increased significantly $\mathrm{K}$ concentration of fruit flesh in 
Table 3. Macro (\%) and micro (ppm) plant nutrient concentration in flesh of grafted watermelon.

\begin{tabular}{cccccccccc}
\hline Graft combinations & $\mathrm{N}$ & $\mathrm{P}$ & $\mathrm{K}$ & $\mathrm{Ca}$ & $\mathrm{Mg}$ & $\mathrm{Fe}$ & $\mathrm{Zn}$ & $\mathrm{Mn}$ & $\mathrm{Cu}$ \\
\hline C.T./Ferro & 1.91 & 0.14 & 1.27 & 0.03 & 0.12 & 76.7 & 7.5 & 3.0 & 2.5 \\
Cr./Ferro & 2.31 & 0.15 & 1.42 & 0.07 & 0.13 & 44.7 & 6.8 & 3.0 & 3.4 \\
C.T./RS841 & 1.11 & 0.13 & 1.24 & 0.08 & 0.11 & 45.1 & 5.5 & 1.8 & 2.8 \\
Cr./RS841 & 1.91 & 0.16 & 1.73 & 0.05 & 0.13 & 40.0 & 7.9 & 2.4 & 4.5 \\
C.T./Macis & 1.71 & 0.17 & 1.33 & 0.08 & 0.11 & 46.4 & 6.0 & 3.1 & 2.3 \\
Cr./Macis & 1.81 & 0.11 & 1.25 & 0.07 & 0.10 & 40.8 & 5.1 & 3.2 & 5.4 \\
C.T./Agentario & 1.51 & 0.13 & 1.18 & 0.07 & 0.10 & 39.0 & 6.3 & 3.4 & 2.7 \\
Cr./Agentario & 1.83 & 0.13 & 1.22 & 0.06 & 0.09 & 32.5 & 6.6 & 2.4 & 4.5 \\
Crimson Tide & 1.60 & 0.15 & 1.34 & 0.07 & 0.12 & 40.7 & 5.5 & 2.8 & 2.3 \\
Crisby & 1.41 & 0.10 & 1.18 & 0.11 & 0.11 & 45.7 & 5.6 & 2.4 & 5.1 \\
Lsd 0.05 & 0.03 & 0.02 & 0.04 & 0.01 & 0.003 & 8.6 & 0.3 & 0.3 & 0.7 \\
\hline
\end{tabular}

Crisby whereas there was no significant effect in Crimson Tide regarding flesh $\mathrm{K}$ content. Cr./RS841 had the highest $\mathrm{K}$ while the lowest $\mathrm{K}$ was found in C.T./Argentario and Crisby.

There was significant decrease in flesh Ca concentration of grafted Crisby while flesh Ca concentration increased by grafting in Crimson Tide except C.T./Ferro. Rootstocks and scion had significant effect on fruit flesh $\mathrm{Mg}$ concentration. Crisby grafted onto Ferro and RS841 had the highest $\mathrm{Mg}$ concentration in the flesh while Crisby grafted onto Argentario and Macis had the lowest $\mathrm{Mg}$ in the flesh. Iron concentration of the flesh changed depending on rootstocks and scions. C.T./Ferro had the highest $\mathrm{Fe}$ concentration of flesh while the lowest $\mathrm{Fe}$ concentration was determined in flesh of $\mathrm{Cr}$./Argentario. Zinc content of the flesh was increased by grafting in both watermelon cultivars, except C.T./RS841 and Cr./ Macis combinations. Manganese concentration of the flesh was significantly increased in grafted plant, except for C.T./RS841. Ungrafted Crisby, Cr./Argentario, Cr./ RS841 and C.T./RS841 had lower Zn concentration in the flesh. Grafting had no significant effect on $\mathrm{Cu}$ concentration of the flesh while $\mathrm{Cu}$ concentration was significantly affected by scion cultivar. Ungrafted Crisby and its graft combination had higher $\mathrm{Cu}$ concentration than Crimson Tide and its graft combinations.

\subsection{Seed}

Mineral composition of seed was not affected by rootstocks and scion, except for Nitrogen and $\mathrm{Cu}$ (Table 4). The highest $\mathrm{N}$ concentration was determined in the seed among analyzed plant organ in this study. Grafting caused significant increase in $\mathrm{N}$ content of the seed in
Crisby and Crimson Tide, except for C.T./Argentario containing lower $\mathrm{N}$ concentration in seed in compare to ungrafted plants. Grafting significantly increased seed $\mathrm{Cu}$ content in both watermelon cultivar. C.T./Macis and $\mathrm{Cr}$./Macis had significantly higher $\mathrm{Cu}$ content in the flesh than other graft combinations. The lowest $\mathrm{Cu}$ concentration in the seed was recorded in Crisby cultivar.

\section{DISCUSSION}

The nutrient concentration ranges of analyzed elements were within the standard or normal values reported for watermelon [26], and any deficiency symptom was not observed. Plant nutrients concentration in the leaf was significantly affected by both rootstocks and scion (Table 1). C.T./Ferro had significantly higher $\mathrm{N}$ concentration while five graft combinations had lower $\mathrm{N}$ content than the control plants in the leaves. Phosphorous concentration was lower in the grafted plants than the controls. This decrease is more apparent in Crisby cultivar. Both rootstocks and scion had significant effect on $\mathrm{K}$ concentration of the leaf. Crimson Tide and its graft combinations had higher $\mathrm{K}$ in their leaves. C.T./Argentario had the highest $\mathrm{K}$ concentration in the leaf. Calcium concentration of leaves was influenced by scion and rootstocks. All grafted plants had significantly lower $\mathrm{Ca}$ concentration in the leaf than the controls, except $\mathrm{Cr}$./ Ferro and Cr./Argentario. Magnesium concentration of the leaf showed increases or decreases based on rootstocks and scions. All grated plants and ungrafted Crimson Tide had similar values regarding leaf $\mathrm{Fe}$ concentration. Grafted plants had lower $\mathrm{Zn}, \mathrm{Mn}$ and $\mathrm{Cu}$ concentration than the controls. These three minerals were significantly affected by rootstocks and scion. 
Table 4. Macro (\%) and micro (ppm) plant nutrient concentration in seed of grafted watermelon.

\begin{tabular}{ccccccccccc}
\hline Graft combinations & $\mathrm{N}$ & $\mathrm{P}$ & $\mathrm{K}$ & $\mathrm{Ca}$ & $\mathrm{Mg}$ & $\mathrm{Fe}$ & $\mathrm{Zn}$ & $\mathrm{Mn}$ & $\mathrm{Cu}$ \\
\hline C.T./Ferro & 3.45 & 0.51 & 0.69 & 0.10 & 0.22 & 28.8 & 28.6 & 9.0 & 11.8 \\
Cr./Ferro & 3.27 & 0.50 & 0.57 & 0.08 & 0.22 & 29.6 & 23.4 & 11.8 & 10.2 \\
C.T./RS841 & 3.50 & 0.53 & 0.71 & 0.11 & 0.23 & 26.7 & 23.5 & 9.9 & 11.5 \\
Cr./RS841 & 3.29 & 0.51 & 0.61 & 0.07 & 0.23 & 34.3 & 25.8 & 11.2 & 11.4 \\
C.T./Macis & 3.01 & 0.51 & 0.76 & 0.10 & 0.22 & 27.0 & 23.6 & 10.8 & 12.6 \\
Cr./Macis & 3.00 & 0.55 & 0.70 & 0.15 & 0.21 & 33.7 & 26.2 & 9.6 & 13.3 \\
C.T./Agentario & 2.55 & 0.44 & 0.65 & 0.08 & 0.19 & 28.1 & 20.3 & 8.1 & 11.3 \\
Cr./Agentario & 3.34 & 0.49 & 0.57 & 0.08 & 0.21 & 31.3 & 22.5 & 9.5 & 10.9 \\
Crimson Tide & 3.04 & 0.54 & 0.74 & 0.10 & 0.19 & 30.5 & 27.6 & 10.9 & 11.2 \\
Crisby & 2.86 & 0.48 & 0.62 & 0.13 & 0.21 & 28.5 & 25.8 & 10.3 & 9.8 \\
Lsd 0.05 & 0.13 & $\mathrm{~ns}$ & $\mathrm{~ns}$ & $\mathrm{~ns}$ & $\mathrm{~ns}$ & $\mathrm{~ns}$ & $\mathrm{~ns}$ & $\mathrm{~ns}$ & 1.7 \\
\hline
\end{tabular}

Our results showed that plant nutrients concentration in the leaf was affected by not only rootstocks but also scion. The effect of the rootstock on the mineral composition of aerial plant parts was principally explained with physical characteristics of the root system, such as lateral and vertical development, which resulted in enhanced uptake of water and minerals [27,28], this being one of the main purposes for the widespread use of rootstocks [3]. However, significant influence of rootstocks on leaf mineral content was not found in grafted fruit trees while scion genotypes was found more effective in changing of leaf mineral content [29]. It was reported that the vigor of the scion and rootstock had an significant role in the uptake and translocation of nutrients in grafted fruit trees [30], while the leaf concentration of certain essential minerals in pistachio plant (Pistachia vera L.) were significantly affected by different rootstocks [31]. Increased utilization of $\mathrm{N}$ grafted melon [16] and watermelon [24] was reported. In grafted Solanaceous crops (tomato and pepper) plant, no significant differences were found in nitrogen concentration between graft combinations (tomato/tomato, tomato/pepper, pepper/tomato and pepper/pepper) [32]. Similarly, there was no significant difference in nitrogen status of grafted watermelon onto different rootstocks under improved alkalinity conditions [19]. In our study, P content slightly was decreased by grafting onto different rootstocks and $\mathrm{P}$ content was affected by both rootstock and scion. In agreement with our results, Ruiz et al. [16] demonstrated that rootstock $\mathrm{x}$ scion interaction was affective on $\mathrm{P}$ concentration of the grafted melon plants. In contrast, in Solanaceous species, Kawaguchi et al. [32]. suggested that rootstocks was has important role on absorption and translocation of $\mathrm{P}$. Grafted watermelon had higher leaf P content under sa- linity [22], alkalinity [19] and heavy metal [18] stress conditions. In agreement with [16], some of the grafted plants had similar K content in the leaf others had lower $\mathrm{K}$ concentration in this study, in other reports significant increase in $\mathrm{K}$ content of leaf was reported in tomato [33] and watermelon [34]. In consistent with Colla et al. [24], $\mathrm{Ca}$ and $\mathrm{Mg}$ were affected both rootstocks and scion and the grafted plant onto pumpkin rootstocks had higher $\mathrm{Mg}$ content than bottle gourd rootstocks.

Micro nutrients were significantly affected by cultivar and scion. Ungrafted control plants higher micro nutrient than the grafted plants except Fe. Similarly, it was reported that grafted cucumber accumulated lower $\mathrm{Cu}$ in shoot of cucumber [18], lower $\mathrm{Cu}$ and $\mathrm{Fe}$ in tomato [35]. Huang et al. [36] reported a decrease in total microelements, but there were no significant differences for $\mathrm{Fe}$, $\mathrm{Mn}, \mathrm{Cu}$ and $\mathrm{Zn}$ compared to ungrafted control plants. The decrease in microelement in grafted plants was explained by ability of the rootstock to exclude excessive micro nutrient $[18,36]$. Therefore, the mineral composition of the plants is influenced by the rootstock and scion characteristics but the impact of the scion and rootstocks may change based on availability of the element and environmental conditions [37].

Nitrogen, $\mathrm{P}$ and $\mathrm{K}$ content of fruit rind was significantly affected by scion and rootstocks. Increases or decreases were observed based on scion/rootstocks combinations. The highest $\mathrm{K}$ concentration was determined in fruit rind among plant organs investigated in this study. Fruit rind harvested from the plant grafted onto pumpkin rootstocks had higher $\mathrm{Ca}$ and $\mathrm{Mg}$ content than the plants grafted onto bottle gourd rootstocks. Similar results with leaf microelements contents were observed in fruit rind except $\mathrm{Mn}$ and $\mathrm{Cu}$. Cr./Ferro had higher $\mathrm{Mn}$ content in 
rind than the control and other grafted plants, and $\mathrm{Cr}$./ Macis and C.T./Ferro accumulated higher $\mathrm{Cu}$ in fruit rind than other treatments.

The fruit flesh harvested from Cucurbita rootstocks had higher $\mathrm{N}$ concentration except C.T./RS841 graft combination. Phosphorous content of the fruit flesh showed significant variation based on rootstock and scion. Cr./Macis, C.T./Argentario, Cr./Macis and ungrafted Crisby had lower $\mathrm{P}$ concentration than others. Grafting increased significantly $\mathrm{K}$ concentration of fruit flesh in Crisby whereas there was no significant effect in Crimson Tide regarding flesh $\mathrm{K}$ content. Flesh $\mathrm{Ca}$ concentration of grafted Crsiby was significantly decreased while flesh $\mathrm{Ca}$ concentration increased by grafting in Crimson Tide except C.T./Ferro. Rootstocks and scion had significant effect on fruit flesh $\mathrm{Mg}$ concentration. Crisby grafted onto Ferro and RS841 had the highest Mg concentration in the flesh while Crisby grafted onto Argentario and Macis had the lowest $\mathrm{mg}$ in the flesh. Iron concentration of fruit flesh was found similar in all treatment except C.T./Ferro. Other micro element also significantly affected by rootstocks and scions.

Mineral composition of seed was not affected by rootstocks and scion, except for Nitrogen and $\mathrm{Cu}$ (Table 4). The highest $\mathrm{N}$ concentration was recorded in seed in investigated plant organs in this study.

Mineral composition of fruit is one of the fruit quality parameters. In our study, mineral composition of the fruits (rind, flesh and seed) was significantly affected by rootstocks and scion. Scott et al. [38] reported the stage of fruit development affected elemental concentrations in the rind tissue and these differed between the blossom and stem ends of the fruits. There was also a significant genotype effect on mineral concentration in rind tissue. Rouphael et al. [18] reported that $\mathrm{P}$ and $\mathrm{Ca}$ content of watermelon was not affected by rootstock while $\mathrm{K}$ and $\mathrm{Mg}$ content was significantly affected by rootstock under deficient irrigation conditions. Yield, external and interior quality characteristics of watermelon fruits in grafted plants are obviously affected by the scion variety but rootstock can change drastically these characteristics. Many conflicting results on changes in fruit quality resulting from grafting were reported [5,7,11,39-41]. The differences in previous studies may be explained with different production conditions, type of rootstock/scion combination.

\section{CONCLUSION}

Mineral composition of leaf, rind and flesh of watermelon was significantly affected by not only the scions but also rootstocks. Any deficiency symptom was not observed during growing period in the leaves and the nutrient concentration ranges of analyzed elements were within the standard or normal values reported for water- melon [26]. The effect of rootstock/scion on mineral composition of fruit rind and flesh is important for fruit shelf life and nutritive value of watermelon. Rootstock/ scion combinations should be carefully selected and cultural practices (plant density, fertilization, irrigation and harvest) should be conducted properly based on the rootstocks/scion combination under specific climatic and geographic conditions. Therefore, information on characteristics of rootstocks and their possible effect on plant growth and fruit quality in related environment should be given by rootstocks suppliers. Appropriate selection of the combinations can help control soilborne diseases and also increase yield and improve fruit quality in watermelon.

\section{REFERENCES}

[1] FAO (2011) Statistical Database. www.fao.org.com. 16.08.2011.

[2] Messiaen, C.M. (1974) Le Potager Tropical (1- généralités). Agence de Coop., Culturelle et Technique Publisher, Paris.

[3] Lee, J.M. (1994). Cultivation of grafted vegetables. I. Current status, grafting methods and benefits, HortScience, 29, 235-239.

[4] Oda, M. (1995) New grafting methods for fruit-bearing vegetables in Japan. Japan Agricultural Research Quarterly, 29, 187-198.

[5] Lee, J.M. and Oda, M. (2003) Grafting of herbaceous vegetable and ornamental crops. Horticultural Reviews, 28, 61-124.

[6] Yetisir, H., Sari, N. and Yücel, S. (2003) Rootstock resistance to fsarium wilt and effect on watermelon fruit yield and quality. Phytoparasitica, 31, 163-169. doi:10.1007/BF02980786

[7] Yetisir., H. and Sar1, N. (2003) Effect of different rootstock on plant growth, yield and quality of watermelon. Australian Journal of Experimental Agriculture, 43, 1269-1274. doi:10.1071/EA02095

[8] Lopez-Galarza, S.A., San Bautista, D.M., Perez, D.M., Miguel, A., Baixauli, C., Pascual, B, Maroto, J.V. and Guardiola, J.L. (2004) Effect of grafting and cytokinin induced fruit setting on color and sugar content traits in glasshouse-grown triploid watermelon. Journal of Horticultural Science and Biotechnology, 79, 971-976.

[9] Yetisir, H., Kurt, S., Sari N. and Tok, M.F. (2007) Rootstock potential of Turkish Lagenaria siceraria germplasm for watermelon: Plant growth, graft compatibility, and resistance to Fusarium. Turkish Journal of Agriculture and Forestry, 31, 381-388.

[10] Pulgar, G., Villora, G., Moreno, D.A. and Romero, L. (2000) Improving the mineral nutrition in grafted watermelon plants: Nitrogen metabolism. Plant Biology, 43, 607-609. doi:10.1023/A:1002856117053

[11] Karaca., F.,Yetisir, H., Solmaz, I., Candir, E., Kurt, S., Sari, N. and Guler, Z. (2012) Rootstock potential of Turk- 
ish Lagenaria siceraria germplasm for watermelon: plant growth, yield and quality. Turkish Journal of Agriculture and Forestry, 36, 167-177.

[12] Bulder, H.A.M., van Hasselt, P.R., Kuiper, P.J.C., Speek, E.J. and den Nijs, A.P.M. (1990) The effect of low root temperature in growth and lipid composition of low temperature tolerant rootstock genotypes for cucumber. Journal of Plant Physiology, 138, 661-666. doi:10.1016/S0176-1617(11)81312-X

[13] Rivero, R.M., Ruiz, J.M., Sanchez, E. and Romero, L. (2003) Does grafting provide tomato plants and advantages against $\mathrm{H}_{2} \mathrm{O}_{2}$ production under conditions of thermal shock? Plant Physiology, 117, 44-50. doi:10.1034/j.1399-3054.2003.1170105.x

[14] Romero, L., Belakbir, A., Ragala, L. and Ruiz, M. (1997) Response of plant yield and leaf pigments to saline conditions: Effectiveness of different rootstocks in melon plants (Cucumis melo L.). Soil Science and Plant Nutrition, 43, 855-862. doi:10.1080/00380768.1997.10414652

[15] Yetisir, H. and Uygur, V. (2010) Responses of grafted watermelon onto different gourd species to salinity stress. Journal of Plant Nutrition, 33, 315-327. doi:10.1080/01904160903470372

[16] Ruiz, J.M., Belakbir, A., Lopez-Cantarero, A. and Romero, L. (1997) Leaf macronutrient content and yield in grafted melon plants: A model to evaluate the influence of rootstocks to genotype. Scientia Horticulturae, 71, 113123.

[17] Cohen, S. and Naor, A. (2002) The effect of three rootstocks on water use canopy conductance and hydraulic parameters of apple trees and predicting canopy from hydraulic conductance. Plant, Cell and Environment, 25, 17-28. doi:10.1046/j.1365-3040.2002.00795.x

[18] Rouphael, Y., Cardarelli, M., Reab, E. and Colla, G. (2008) Grafting of cucumber as a means to minimize copper toxicity. Environ. Journal of Experimental Botany, 63, 49-58. doi:10.1016/j.envexpbot.2007.10.015

[19] Colla, G., Rouphaelb, Y., Cardarelli, M., Salernoc, A. and Reac, E. (2010) The effectiveness of grafting to improve alkalinity tolerance in watermelon. Environmental and Experimental Botany, 68, 283-291. doi:10.1016/j.envexpbot.2009.12.005

[20] Yetisir, H., Caliskan M.E, Soylu, S. and Sakar M. (2006) Some physiological and growth responses of watermelon [Citrullus lanatus (Thunb.) Matsum and Nakai] grafted onto Lagenaria siceraria to flooding. Environmental and Experimental Botany, 58, 1-3. doi:10.1016/j.envexpbot.2005.06.010

[21] Yetisir, H. (2001) Karpuzda aşılı fide kullanımının bitki büyümesi, verim ve meyve kalitesi üzerine etkileri ile aş1 yerinin histolojik açıdan incelenmesi, Ph.D. Thesis, $\mathrm{Cu}-$ kurova University, Adana.

[22] Uygur, V. and Yetisir, H. (2009) Effects of rootstocks on some growth parameters, phosphorous and nitrogen uptake watermelon under salt stress. Journal of Plant Nutrition, 32, 629-643. doi:10.1080/01904160802715448

[23] Curuk, S., Dasgan, H.Y., Mansuroglu S., Kurt, S., Mazmanoğlu, M., Tarla, G. and Durgac, C. (2010) Leaf mineral composition of grafted eggplant grown in soil infested with verticillium and root-knot nematodes. Pes- quisa Agropecuaria Brasileira, 45, 879-885.

[24] Colla, G., Suarez, C.M.C., Cardarelli, M. and Rouphael, Y. (2010) Improving nitrogen use efficiency in melon by grafting. HortScience, 45, 559-565.

[25] SAS (2006) Institute, SAS Online Doc, Version 8. SAS Inst Cary.

[26] Bergmann, W. (1992) Nutritional disorders of plant-development, visual and analytical diagnosis.

[27] Heo, Y.C. (1991) Effects of rootstocks on exudation and mineral elements contents in different parts of Oriental melon and cucumber (in Korean with English summary). M.S. thesis, Kyung Hee University, Seoul.

[28] Jang, K.U. (1992) Utilization of sap and fruit juice of Luffa cylindrica L. Res. Rpt., Korean Ginseng and Tobacco Institute, Taejon.

[29] Chaplin, M.H. and Westwood, M.N. (1980) Nutritional status of "Bartlett" pear on Cydonia and Pyrus species rootstocks. Journal of American Society Horticultural Science, 105, 60-63.

[30] Tagliavani, M., Bassi, D. and Marangoni, B. (1993) Growth and mineral nutrition of pear rootstocks in lime soils. Scientia Horticulturae, 54, 13-22. doi:10.1016/0304-4238(93)90079-6

[31] Brown, P.H., Zhang, Q. and Ferguson, L. (1994) Influence of rootstock on nutrient acquisition by pistachio, Journal of Plant Nutrition, 17, 1137-1148. doi:10.1080/01904169409364794

[32] Kawaguchi, M., Taji, A., Backhouse, D. and Oda, M. (2008) Anatomy and physiology of graft incompatibility in solanaceous plants. Journal of Horticultural Science and Biotechnology, 83, 581-588.

[33] Fernández-García, N., Carvajal, M. and Olmos, E. (2004) Graft union formation in tomato plants. Peroxidase and catalase involvement. Annals of Botany, 93, 53-60. doi:10.1093/aob/mch014

[34] Goreta, S., Bucevic-Popovic, V., Selak, G.V., PavelaVrancic, M. and Perica, S. (2008) Vegetative growth, superoxide dismutase activity and ion concentration of saltstressed watermelon as influenced by rootstock. Journal of Agricultural Science, 146, 695-704. doi:10.1017/S0021859608007855

[35] Savvas, D., Papastavrou, D., Ntatsi, G., Ropokis, A., Olympios, C., Hartmann, H. and Schwarz, D. (2009) Interactive effects of grafting and manganese supply on growth, yield, and nutrient uptake by tomato. HortScience, 44, 1978-1982.

[36] Huang, Y., Bie, Z., He, S., Hua, B., Zhen, A. and Liu, Z. (2010) Improving cucumber tolerance to major nutrients induced salinity by grafting onto Cucurbita ficifolia. Environmental and Experimental Botany, 69, 32-38. doi:10.1016/j.envexpbot.2010.02.002

[37] Carmen Martínez-Ballesta, M., Alcaraz-Lópeza, C., Muriesa, B., Mota-Cadenasa, C. and Carvajal, M. (2010) Physiological aspects of rootstock-scion interactions. Scientia Horticulturae, 127, 112-118. doi:10.1016/i.scienta.2010.08.002

[38] Scott, W.D., McCraw, B.D., Motes, J.E. and Smith, M.W. 
(1993) Application of calcium to soil and cultivar affect elemental concentration of watermelon leaf and rind tissue. Journal of American Society Horticultural Science, 118, 201-206.

[39] Salam, M.A., Masum, A.S.M.H., Chowdhury, S.S., Dhar, M., Saddeque, A. and Islam, M.R. (2002) Growth and yield of watermelon as influenced by grafting. Journal of Biological Sciences, 2, 298-299.

doi:10.3923/jbs.2002.298.299
[40] Davis, A.R. and Perkins-Veazie, P. (2005) Rootstock effects on plant vigor and watermelon fruit quality. Cucurbit Genet. Cucurbit Genetics Cooperative Reports, 28-29, 39-42.

[41] Colla, G., Raupahel, Y., Gardarelli, M. and Rea, E. (2006) Effect of salinity on yield fruit quality, leaf gas exchange and mineral composition of grafted watermelon plants. HortScience, 41, 622-627. 